\title{
Socio-demographic Heterogeneity in Prevalence of SARS-COV-2 Infection and Death Rate: Relevance to Black College Student Knowledge of COVID-19 and SARS-COV-2
}

\author{
Jahangir Emrani ${ }^{1} \cdot$ Elia Nichelle Hefner ${ }^{1}$ \\ Received: 26 July 2021 / Revised: 17 November 2021 / Accepted: 17 November 2021 / Published online: 4 February 2022 \\ (c) W. Montague Cobb-NMA Health Institute 2022
}

\begin{abstract}
Black and Brown communities are affected disproportionately by COVID-19. In an attempt to learn if young Black college students unknowingly contribute to the spread of the COVID-19 in their communities, using surveys, this pilot study gauges the general safety knowledge and basic scientific knowledge of Black college students about SARS-COV-2 virus and COVID-19 at an HBCU. We also investigated whether students enrolled in chemistry courses designed for STEM (Science, Technology, and Engineering Majors) majors displayed increased knowledge of SARS-COV-2 and COVID-19 in comparison to their non-STEM major peers. Two sets of surveys with multiple choice questions, one with 25 and the other with 34 questions, were designed to assess general safety knowledge and basic scientific knowledge of the students about COVID-19 and the SARS-COV-2 virus. Survey questions were administered through Blackboard learning management system to one hundred eighty-seven (187) students in the summer of 2020 to two freshman non-science majors and in the fall of 2020 to one freshman non-science-major class, two freshmen STEM-major classes, and one senior STEM-major class. All students self-registered in the 6 chemistry classes at North Carolina A\&T State University at random with no predetermined criteria. Results of the study show that regardless of their year of study, majority $(>90 \%)$ of the students possess basic scientific knowledge and are aware of the safety precautions concerning SARS-COV-2 virus and COVID-19. Majority of non-science major freshmen answered the basic safety questions correctly but were not able to choose the correct answers for the more specific scientific questions concerning SARS-COV-2 and COVID-19. Surprisingly, there was no significant difference in basic scientific knowledge regarding SARS-COV-2 and COVID-19 between STEM and non-STEM student populations, and first year STEM students were just as knowledgeable as senior STEM students. Based on these data, we speculate that students surveyed here have an acceptable basic understanding of how SARS-CoV-2 is transmitted, and therefore, they may not be a source of COVID-19 transmission to Black and Brown communities as this study confirms they are receiving accurate information about SARS-COV-2 and COVID-19. Possession of crucial timely and accurate knowledge about the health and safety is important in fighting racism and to gain equity within the society at large. By sharing the acquired knowledge, students can serve as positive role models for others in the community thus encouraging them to pursue science. Education brings equity, sharing the acquired knowledge encourages others to continue their education and succeed in obtaining higher degrees and better jobs as remedies for social inequality. Spread of accurate knowledge on various aspects of COVID-19 will also help remove fears of vaccination and hesitation towards visits to health clinics to resolve health issues. Relying on the results of this pilot study, we plan to explore these important factors further in our next study.
\end{abstract}

Keywords BIPOC (Black, Indigenous, People of Color) - African Americans · Education · Socioeconomic status · Infection, transmission · College student knowledge $\cdot$ COVID-19 $\cdot$ STEM $\cdot$ Racial/ethnic $\cdot$ Health disparities $\cdot$ Pandemic . Disproportionate infectivity and mortality

\section{Introduction}

Jahangir Emrani

emrani@ncat.edu

Extended author information available on the last page of the article
COVID-19 caused by SARS-COV-2 is a pandemic that has moved to every country in the world.[1] The disease has killed over five million people and has slowed or stopped 
major economic activities in all countries. It also has caused a jam in the hospitals so that at times, major medical centers simply do not have enough room, doctors, and nurses to take care of all incoming patients. In the USA, COVID-19 which has infected $>47$ million and as of November 14, 2021 has killed 763, 000 people, disproportionately infects and kills people of color (Fig. 1) [2]. African Americans make up $13 \%$ of the US population but one-third of the hospitalizations from COVID-19 $[3,4]$. In some locations, $>70 \%$ of those who died from the disease are African Americans. [5, 6] A similar trend has been observed among other minorities like Latinx and Native Americans. Among the minorities, the main victims of the disease are older adults, especially those with pre-existing conditions such as heart and lung disease, diabetes, and obesity (Fig. 1). According to some sources, the number of minorities who lost their lives to COVID-19 has been underestimated [7]. Although less susceptible themselves, young people can transmit the disease to older adults in their families, which hold the very fabric of the Black and Brown communities together. Educating the underserved individuals, their families, and communities about the virus and various aspects of the pandemic is to recognize the inequities of the past and to create conditions that improves these underserved communities. Universities are in a unique position to educate and spread the awareness about the pandemic, reduce vaccine hesitancy,
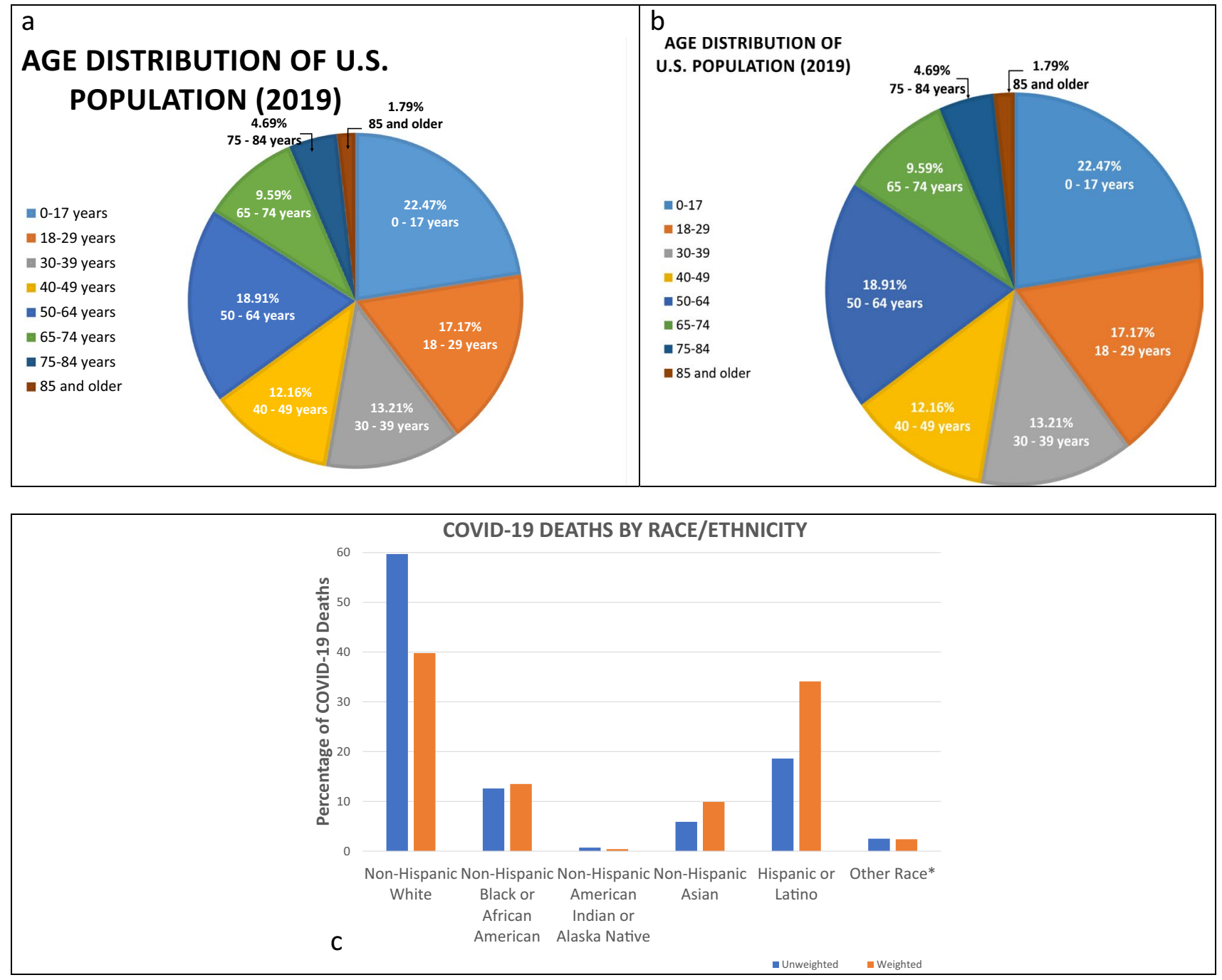

Fig. 1 a Age distribution of COVID-19 casualties and COVID19 deaths by race/ethnicity among Black, Hispanic, and other race/ ethnic groups relative to Non-Hispanic White population in the US. Data were collected from the CDC and are current through October 27, 2021 (https://www.cdc.gov/nchs/nvss/vsrr/covid_weekly/). Unweighted and weighted population distributions are shown, illustrating the overrepresentation of people of color in COVID-19 deaths.
Other race percentages combine Non-Hispanic Native Hawaiian or Other Pacific Islander and Non-Hispanic more than one race data. b Age distribution of US population according to the US Census Bureau in 2019 (https://www.census.gov/data/tables/2019/demo/ age-and-sex/2019-age-sex-composition.html). c Unweigthed and weighted COVID-19 death by race/ethnicity in the USA 
and reinforce the need for attention to healthcare, social distancing, proper handwashing, and wearing masks among young adults. Young students can in turn play a pivotal role in their communities-increasing vaccine awareness and overall empowerment of minorities to seek medical attention when necessary in relation to COVID-19 and other medical maladies. One area of special interest during the COVID19 pandemic is how to eliminate vaccine hesitancy. This is a particularly difficult obstacle to overcome due to the past negative experiences of Blacks such as the Tuskegee Study of Untreated Syphilis in the Negro Male, where Black men were not informed of the diagnosis, denied treatment, and exploited. Distrust coupled with lack of understanding makes vaccination of Black and Brown communities difficult. Basic knowledge about vaccines such as how antibodies form and bind to foreign pathogens to prevent them from entering cells can and should be part of introductory chemistry and first year STEM-major courses. From introducing functional groups and intermolecular interactions to teaching enzyme reaction mechanisms, there are many chemistry topics that can be taught using infection and the immune system as case studies. Inclusion of such material provides novel links between chemistry and healthcare that traditional chemistry courses lack. The link provides the students with relevant information that can be passed on to their peers and family members. The link also creates an opportunity for chemistry educators to encourage dialog between students around the topic of vaccination and COVID-19, enabling them to share what they know and fill in knowledge gaps as needed. Information gleaned in class through discussion can be disseminated to Black and Brown communities through students where the innate trust between them and their loved ones will help ease distrust of the medical and scientific community such that valid treatment methods and vaccines will be more widely accepted and encouraged. Equity begins with leveling the education playing field. Emphasizing the chemistry links to health and wellness may serve to spark interest in Black and Brown college students to be better informed about their own health and wellness and that of their communities.

Most non-STEM students are required to take an introductory science course as part of their graduation requirements. These introductory courses can incorporate current health-related events, such as the COVID-19 pandemic, into the curriculum as examples of biology and chemistry in the real world. Choosing a recurring theme to add relevance will pique student interest and would help students engage and retain more information for later application. As an example, abstract concepts such as quantum mechanical model of the atom in which many students struggle may be replaced with more practical topics related to health and safety such as study of the mechanism of disinfection of PPE using various disinfectants including hydrogen peroxide and alcohol.
When introducing mole calculations and concentration calculations, sample problems can be formed around the premise of preparing liquid solutions of each disinfectant at the appropriate concentration for disinfection. Introducing realworld chemistry applications in non-major science courses is one way to reach many students who otherwise would not be exposed to these ideas. In upper-level STEM courses, such as organic chemistry, more specific interactions between biological entities may be included.

\section{Chemistry Connection}

It is essential that in science courses such as chemistry, young black and brown people, especially those attending the universities and colleges receive accurate and reliable basic information about the behavior of SARS-COV-2 virus such as its transmissibility, seriousness of the disease, and preventive measures. College students, who are more mobile than older adults, also need to understand the processes involved in the infection, testing, and prevention to avoid spreading the disease to their parents, grandparents, and communities. Understanding these processes at the molecular level deepens their knowledge and increases their awareness and enhances their confidence so that they start becoming the source of knowledge for others. This in turn will lead to developing research interests in these areas where they will be enabled to acquire, analyze, and disseminate knowledge about various aspects of the pandemic including epidemiology, diagnosis, isolation, treatments, antiviral agents, antibodies, and vaccines. Below, connection between infection, transmission, transcription and translation, prevention, and treatment of COVID-19 and chemistry that can be incorporated in undergraduate chemistry courses are briefly described.

\section{Infection}

Infection results from the interaction of the SARS-COV-2 spike protein with angiotensin-converting enzyme 2 (ACE2) receptor which is present on the surface of some cells in the human lung, heart, GI, and nose [8, 9]. The interaction involves van der Waals forces as well as hydrogen bond interaction between the amino acids that make up the protein molecules of the receptor and the spike protein on the virus surface (Fig. 2) [10]. Structural biologists are working to create a more precise model of this interaction [11]. Upon successful interaction, transmembrane protease, serine 2 (TMPRSS2) enzyme located in the human cell membrane cleaves the spike protein which prepares it for fusion with the human cell. An enzymatic process which uses the host furin enzyme completes the fusion of the virus to the surface of the host cell by cleaving the bond between the 


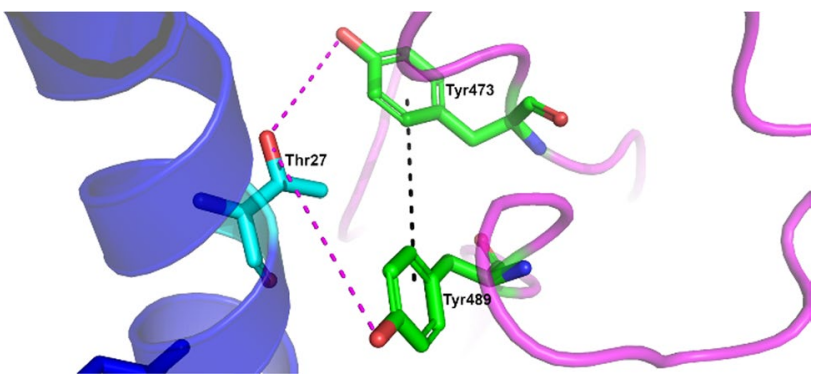

Fig. 2 Interactions between the spike protein receptor binding domain and ACE2 receptor (PDB ID 7KMB) involving hydrogen bonds (magenta dashed lines) and $\pi-\pi$ interactions (black dashed line) [14]

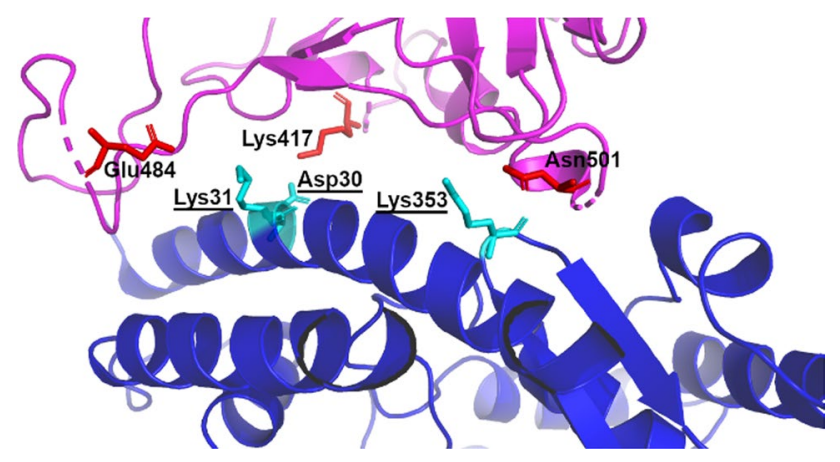

Fig. 3 Spike protein receptor binding domain interacting with ACE2 (PDB ID 7KMB). Spike protein residues Glu484, Lys417, and Asn501 are mutated in SARS-COV-2 variants, increasing the interaction between the viral protein and the ACE2 receptor (select residues involved in receptor binding are underlined)

two segments of the S-protein (S1 and S2) and exposing the peptide that initiates the fusion process [12]. Many factors including age and gender as well as smoking and health of the individual influence the expression of ACE2 and TMPRSS2 influencing susceptibility and pathogenesis [13].

In the more aggressive Alpha and Delta variants of the virus which are more transmissible, the interaction between the receptor protein and the viral spike protein is up to $50 \%$ stronger. This makes these variants highly infective with rapid rate of transmission (Fig. 3) [15]. The increase in the tighter bonding between the receptor and the spike protein is a result of replacement of asparagine-501 in the spike protein with tyrosine in both variants, which increases transmissibility [16].

\section{Transmission}

Transmission occurs when airborne viral particles riding on tiny particles called aerosols and droplets move from an infected person to a healthy individual through the air causing infection. Size of the aerosol and droplet particles and the charge on their surfaces as well as the moisture in the air and presence of mask are some factors that determine the likelihood of transmission. Most effective masks like N95 electrostatically block the tiny aerosols and stop the droplets from entering [17]. The viral particles that are not trapped enter the host lung causing infection. The tighter binding between the S-protein and Ace2 receptor makes SARS-COV-2 transmission faster than SARS-COV virus. Another reason for the rapid transmission of SARS-COV-2 is the shedding of infectious virus 2-3 days prior to the onset of symptoms.

\section{Transcription and Translation}

Once inside the host cell, utilizing host ribosome (a macromolecule comprised of RNA and proteins), all 29 viral proteins are synthesized which include structural, non-structural, and accessory proteins. Synthesizing proteins utilizes transfer RNAs (responsible for nucleic acid code recognition and bringing the proper amino acid to the ribosome), amino acids, and mRNA of the host cell [18]. Of the 29 proteins, four including S-protein form the structure of the virus. A large polyprotein is broken in 11 locations by the enzyme main protease to create 16 non-structural proteins which have a vital role in the survival and replication of the virus [19]. Two intermediary proteins ppla and pplab result from translation of ORF1a and ORF1b starting from the 5' side of viral genome [20]. Other important enzymes include RNA primase, helicase, endo- and exoribonuclease, RNA binding proteins, and methyl transferases. Nine subgenomic mRNAs encode accessory proteins and the structural proteins $\mathrm{N}, \mathrm{M}, \mathrm{S}, \mathrm{L}$, etc. Among these proteins are enzymes and accessory factors required for production and packaging of new viral particles [21]. New viral RNA is synthesized through transcription and then undergoes post-transcriptional modifications to be protected from degradation and to help regulate its transcription [22]. All synthesized proteins undergo post-translational glycosylation on their surface to prepare them for their intended functions [23]. At the end, all viral components are packaged in vesicles to form virion particles which are released to initiate new infection upon enzymatic digestion of the cell wall.

\section{Prevention, Diagnosis, and Treatment}

\section{Prevention}

1. Chemistry provides tools that are used to prevent, diagnose, and treat infection by SARS-COV-2 [24-28]. Infection can be prevented by antibodies, proteins generated by our immune system, whose production is triggered by antigens (foreign substance which induces an immune response such as production of antibodies) including vaccines that block the attachment and fusion of the spike protein to ACE2 receptor [29, 30]. Vaccines are produced using several different ways which include the use of whole virus, spike protein of the virus, or 
genetic material carrying the information for the synthesis of antigenic proteins inside the host cell [31]. In the two prominent mRNA vaccines, designed and produced by Moderna and Pfizer-BioNTech (Fig. 4), synthetic mRNA made by chemists is encapsulated inside lipid nanoparticles and injected into the arm muscles of people as vaccine. The mRNA from vaccine is taken up by the human cells which serve as blueprint for the synthesis of antigenic spike protein against which antibody is produced by our immune system [32]. In the case of J\&J and Astrazeneca's vaccines, adenoviral vectors containing the DNA encoding SARS-COV-2 spike protein are used as antigen for inducing antibody [33].

Vaccines trigger the formation of antibodies against the viral S-protein and stop the virus from infecting the human cells. In the mRNA vaccines (Fig. 4), mRNA that codes for spike protein is encapsulated in lipid nanoparticles where specially designed ionizable lipids assist in delivery of the mRNA into human cells and in releasing the mRNA inside the human cells under slightly different $\mathrm{pH}$ conditions (Fig. 4). For diagnosis, techniques such as CRISPR [34] and LAMP (loop-mediated isothermal amplification) [35, 36] have been employed [28]. CRISPR is a gene-editing tool that uses an enzyme called Cas coupled with guide RNA, to detect the genetic signature of the SARS-COV-2 virus.
LAMP is a diagnostic tool that is similar to PCR method but is much faster and makes the diagnostic tests for SARSCOV-2 quicker [37].

\section{Treatment}

For treatment of patients with COVID-19, in addition to antibodies produced through vaccination inside the human body, antibodies and peptides produced outside the body can also be manufactured and used which bind to the viral $\mathrm{S}$-protein to stop it from infecting human cells. Drugs such as remdesivir and Molnupiravir are used to inhibit the enzyme RNA-dependent RNA polymerase (RdRp) [38]. The old drug, dexamethasone, which is a steroid was found to calm "cytokine storm" which results when our immune system goes to overdrive and causes serious conditions in the COVID-19 patients [39]. Other drugs targeting enzymes such as main protease (also called $\mathrm{M}^{\text {pro }}$ or $3 \mathrm{CL}$ protease) are under development [40]. Although synthesis of drugs are covered in organic chemistry courses, their general structural properties such as polarity, solubility, toxicity, design, and manufacturing parameters and mechanism of their action are relevant to topics in general chemistry. Also, properties, manufacture, and mechanism of action of monocolonal and polycolonal antibodies which are effective against COVID19 can be covered in such courses [41-44].

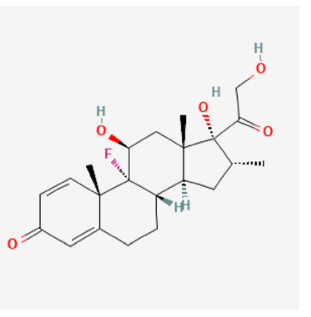

Dexamethasone

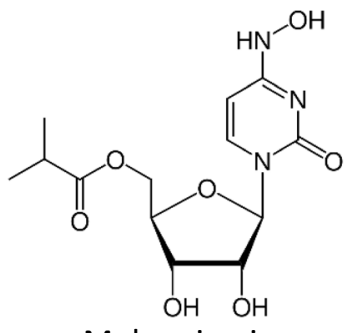

Molnupiravir

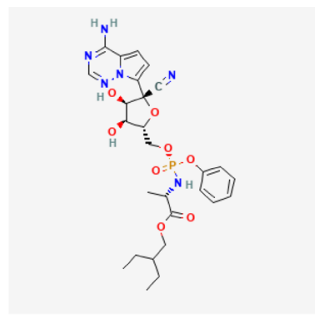

Remdesivir

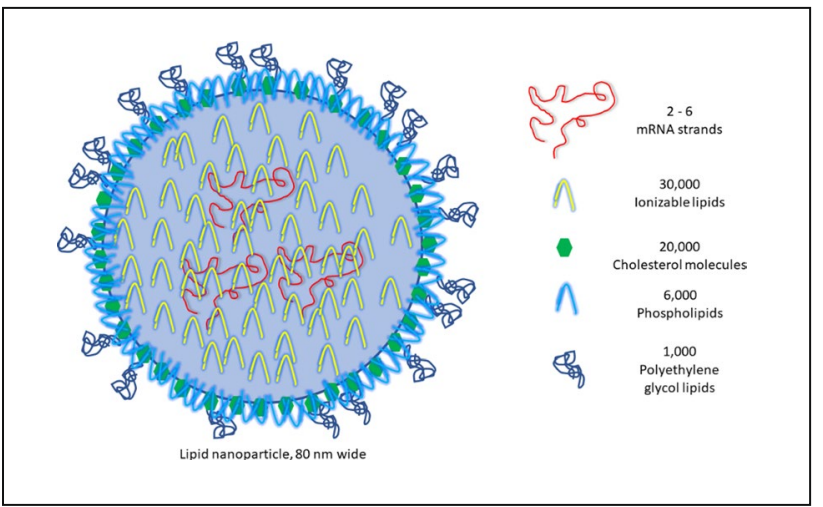

Fig. 4 Drawing shows components of the mRNA vaccine in lipid nanoparticle: mRNA strands are shown inside the lipid nanoparticle. Other components include polyethylene glycol lipids, phospholipids, cholesterol, and ionizable lipids which are crucial components of the vaccine $[28]$

\section{Basic Knowledge and Safety Surveys}

To avoid interruptions in student education during the COVID-19 pandemic, universities and colleges including North Carolina A\&T State University (NCAT) devised plans to allow students to continue their education while minimizing transmission of COVID-19. Soon, these plans added emphasis on educating students about the behavior of the disease and modes of its transmission. To test the knowledge of our students about the pandemic and to see if they have sufficient knowledge which would help them avoid transmitting the disease to their communities, we asked: Are students enrolled in our chemistry courses at North Carolina A\&T State University armed with 
the basic scientific and safety knowledge needed to protect themselves and the elderly in their communities when they come in contact? Also, by extrapolation, do students have sufficient scientific knowledge to potentially pique their interest in scientific research? Do they have accurate knowledge to be confident enough to serve as a resource for others in their communities?[45] Do STEM-major students in these courses have more advanced understanding of the virus than their non-STEM major peers, and if so, is there a significant difference in understanding between first year and senior STEM students? To answer these questions, two surveys about COVID-19 were designed and administered to undergraduate students taking chemistry courses at NCAT, which is an HBCU. The basic safety survey given in the first half of the semester covered topics including infection, pandemic, virus, prevention, treatment, and transmission of the disease. The scientific survey given in latter half of the semester dealt with the biology and biochemistry of infection and transmission in addition to questions about testing, vaccination, and treatment of those who are infected. The results of the study are presented below.

\section{Methods}

Survey Administration Two sets of surveys with multiple choice questions, one with 25 questions and one with 34 questions, were administered to 187 undergraduate students enrolled in 6 chemistry classes at North Carolina A\&T State University in the summer and fall of 2020. Two freshmen chemistry classes in the summer and one in the fall were enrolled by non-science majors. Two other freshman classes along with one senior class in the fall 2020 majored in STEM including chemistry and biology. Students self-enrolled in all classes at random with no predetermined criteria. Survey questions were administered through Blackboard learning system and students answered them at the time of their choosing. Everyone participated and to encourage participation, all students received same number of extra points for completing the surveys. Overall, twenty eight students did not take the surveys. All questions and answers were designed by the authors based on scientific soundness of the relevant concepts.

Data Analysis For data analysis, Microsoft Excel was used to add the percentages of the students who chose one of the 4-5 given answer choices for each question. Only answer choices that were chosen by over $10 \%$ of the students were considered significant and reported. An average was also calculated for the percentages of the students who chose each answer choice. The total percent of students who chose the correct answers were also calculated. Correct answer percentages for each question were also aggregated for
non-STEM and STEM students and compared using a twotailed $t$ test. The same parameters were used to compare correct answer percentages between the senior STEM class and each first year STEM class.

\section{Results}

Results of the surveys are presented in Tables 1 and 2 and in graph form in Figs. 5 and 6. In Table 1, the percent of students who chose the correct answer for the scientific questions, the correct answer choice for each question, and percent of the students who chose the correct answer for each question about SARS-COV-2 and COVID-19 are reported. In Table 2, the questions covering basic safety knowledge about COVID-19, the correct answer choice for each question, and percent of the students who chose the correct answer for each question are listed. All data in both tables are plotted and included in Figs. 5 and 6, respectively.

\section{Discussion}

COVID-19 the disease caused by SARS-COV-2 is primarily transmitted through clusters that include families, communities, gatherings, transportation, shopping malls, conferences, tourists, religious organizations, workers, prisons, offices, and nursing [47]. The disease may be mild, serious, or deadly. Serious conditions leading to death have been more prevalent among older people and minorities. Inequalities between races in access to healthcare have been cited as a major factor causing higher infection and death rate among minorities [48]. Mechanisms that lead to racial/ethnic inequalities in SARS-COV-2 infection and death among older adults have been identified as (a) risk of exposure, (b) weathering processes (gradual decrease in healthiness), and (c) healthcare access and quality [49].

As people age, significant changes in the expression of their genes result in poor prognosis if they contract COVID19 [50]. Many older adults have developed natural immunity against flu viruses, but they do not have immunity against the SARS-COV-2 virus [51]. Acquiring immunity through vaccination has also not been possible because at the beginning of the pandemic, no vaccine was available against SARSCOV-2 [52]. Young people are at lower risk of dying from COVID-19 (Fig. 1). However, if infected with SARS-COV-2 virus, they can transmit the virus to older adults and cause sickness and death among them [53]. In fact, in the Southern United States, based on the percentage of positive SARSCoV-2 cases, one study has shown that younger adults likely contributed to the community transmission of COVID-19 [54]. Over the course of 2020, the average age of those who 


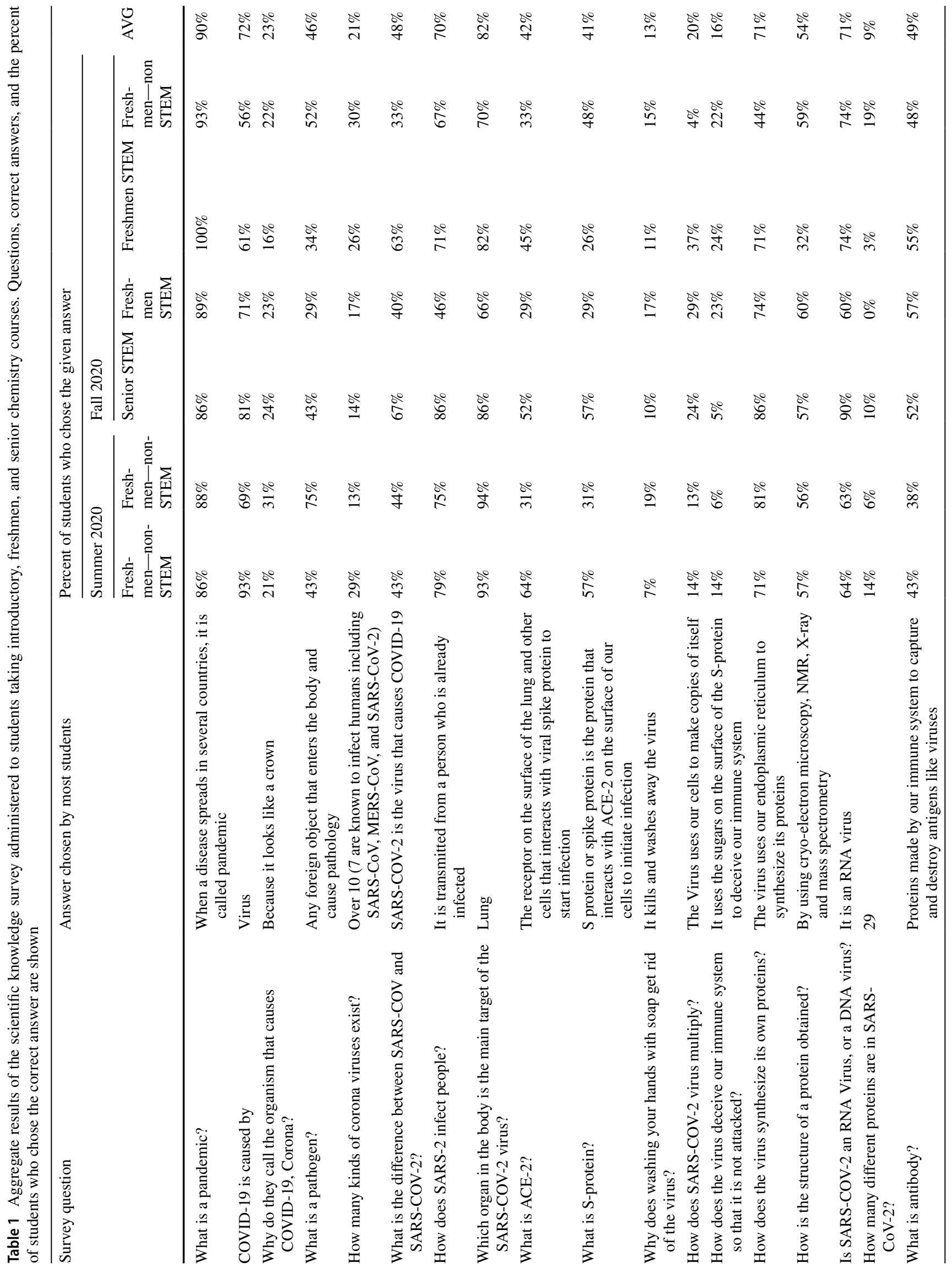




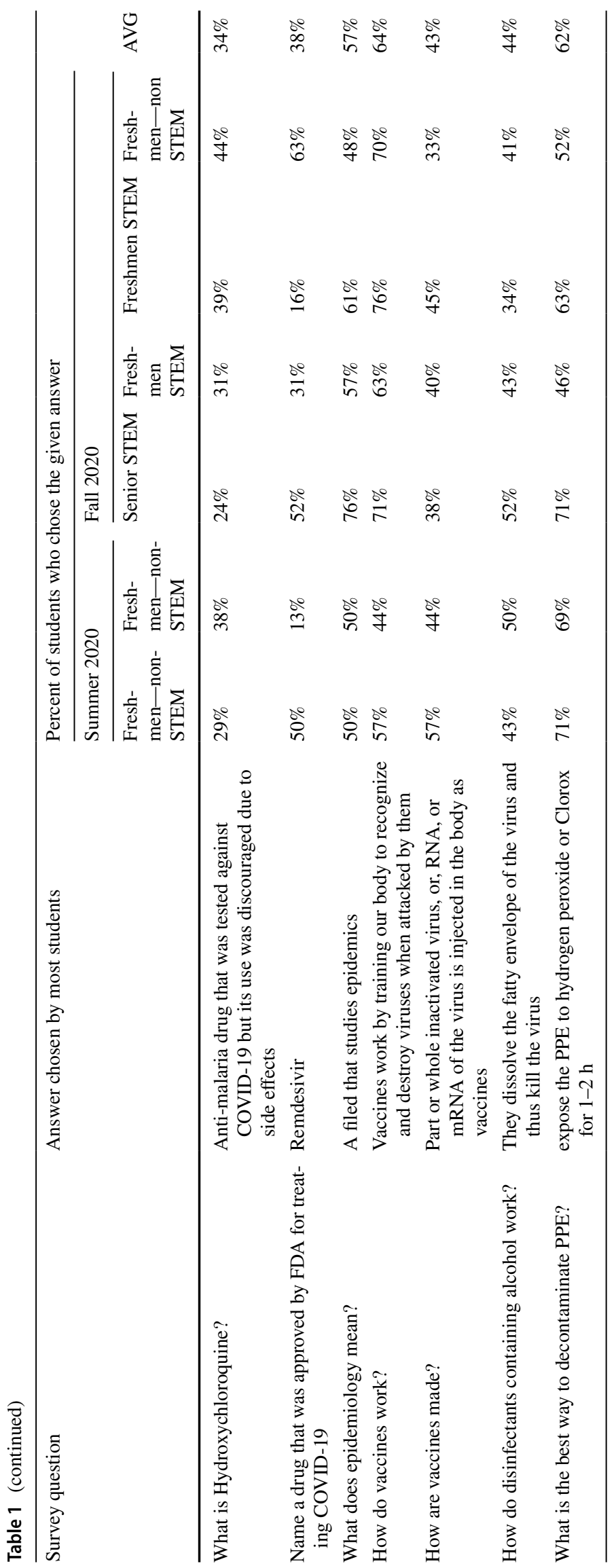


Table 2 Aggregate results of the basic safety knowledge survey administered to students taking introductory, freshmen, and senior chemistry courses, fall 2020. Questions, correct answers, and the percent of students who chose the correct answer are shown

\begin{tabular}{|c|c|c|c|c|c|c|}
\hline \multirow[t]{2}{*}{ Survey question } & \multirow[t]{2}{*}{ Response from $>10 \%$ of students } & \multicolumn{5}{|c|}{$\begin{array}{l}\text { Percent of students who chose the given answer } \\
\text { Fall } 2020\end{array}$} \\
\hline & & $\begin{array}{l}\text { Freshman } \\
\text { STEM }\end{array}$ & $\begin{array}{l}\text { Freshman } \\
\text { STEM }\end{array}$ & $\begin{array}{l}\text { Senior } \\
\text { STEM }\end{array}$ & $\begin{array}{l}\text { Introductory } \\
\text { Non-STEM }\end{array}$ & AVG \\
\hline \multirow[t]{2}{*}{$\begin{array}{l}\text { How is corona virus transmitted from one } \\
\text { person to another person? }\end{array}$} & $\begin{array}{l}\text { By inhaling the air that is exhaled by an } \\
\text { infected person }\end{array}$ & 91 & 94 & 76 & 75 & 84 \\
\hline & $\begin{array}{l}\text { By touching the infected person even while } \\
\text { wearing mask, gloves, and shield }\end{array}$ & 9 & 6 & 24 & 25 & 16 \\
\hline \multirow[t]{2}{*}{$\begin{array}{l}\text { I will be protected from catching COVID- } \\
19 \text { if I }\end{array}$} & $\begin{array}{l}\text { Wear the blue surgical mask and wash my } \\
\text { hand after any potential contact when I } \\
\text { get back home }\end{array}$ & 91 & 84 & 91 & 75 & 85 \\
\hline & $\begin{array}{l}\text { Stay } 6 \text { feet away from other people that I } \\
\text { think may be having the virus }\end{array}$ & 9 & 16 & 6 & 21 & 13 \\
\hline $\begin{array}{l}\text { I don't need to wear any protective devices } \\
\text { against COVID-19 if: }\end{array}$ & $\begin{array}{l}\text { I am always home alone and have no con- } \\
\text { tact with the outside world even for food }\end{array}$ & 97 & 97 & 94 & 92 & 95 \\
\hline Who is more susceptible to COVID-19? & $\begin{array}{l}\text { COVID-19 is more dangerous for people } \\
\text { with breathing and heart problems, obese, } \\
\text { or have diabetes }\end{array}$ & 91 & 90 & 94 & 96 & 93 \\
\hline \multirow{2}{*}{$\begin{array}{l}\text { What is the risk of someone with COPD } \\
\text { from dying of COVID-19? }\end{array}$} & Risk is very high & 57 & 81 & 70 & 58 & 66 \\
\hline & $\begin{array}{l}\text { Low risk if the person with COPD stays } \\
\text { away from all situations where he can be } \\
\text { exposed to the virus }\end{array}$ & 40 & 13 & 27 & 38 & 29 \\
\hline \multirow[t]{3}{*}{$\begin{array}{l}\text { If I have a common flu, will I be in higher } \\
\text { risk of dying, if I also catch COVID-19? }\end{array}$} & $\begin{array}{l}\text { We really don't know the answer to this } \\
\text { question }\end{array}$ & 31 & 71 & 30 & 33 & 42 \\
\hline & $\begin{array}{l}\text { Since your respiratory system may be } \\
\text { compromised, you will have higher risk } \\
\text { for dying }\end{array}$ & 66 & 29 & 70 & 54 & 55 \\
\hline & $\begin{array}{l}\text { If also coughing, have fever, and are out of } \\
\text { breath, isolate and call for help }\end{array}$ & 89 & 90 & 97 & 79 & 89 \\
\hline $\begin{array}{l}\text { In case of heart attack, is it wise to go to } \\
\text { hospital during COVID pandemic? }\end{array}$ & Yes, definitely and immediately & 89 & 90 & 85 & 75 & 85 \\
\hline \multirow[t]{3}{*}{$\begin{array}{l}\text { I live in a hot climate, should I still be wor- } \\
\text { ried about catching COVID-19? }\end{array}$} & $\begin{array}{l}\text { Yes, people of all climates can catch } \\
\text { COVID-19 }\end{array}$ & 83 & 94 & 79 & 71 & 82 \\
\hline & $\begin{array}{l}\text { People in hot climates are less likely to } \\
\text { catch COVID-19 }\end{array}$ & 9 & 3 & 12 & 13 & 9 \\
\hline & $\begin{array}{l}\text { People of all climates have equal chance of } \\
\text { catching COVID-19 }\end{array}$ & 9 & 3 & 9 & 13 & 8 \\
\hline \multirow[t]{2}{*}{ What causes COVID-19? } & SARS-COV-2 virus causes COVID-19 & 83 & 87 & 94 & 67 & 83 \\
\hline & $\begin{array}{l}\text { Actually, COVID-19 is caused by a bac- } \\
\text { teria }\end{array}$ & 11 & 3 & 3 & 17 & 9 \\
\hline \multirow[t]{2}{*}{$\begin{array}{l}\text { What is the origin of SARS-COV-2 virus } \\
\text { that causes COVID-19? }\end{array}$} & $\begin{array}{l}\text { SARS-COV- } 2 \text { originated from wild ani- } \\
\text { mals, bats are potential reservoir }\end{array}$ & 77 & 84 & 70 & 67 & 74 \\
\hline & $\begin{array}{l}\text { SARS-COV-2 has always been living } \\
\text { within human population }\end{array}$ & 20 & 10 & 27 & 21 & 19 \\
\hline \multirow[t]{2}{*}{ How viruses travel across the oceans? } & $\begin{array}{l}\text { The virus gets into people and travels with } \\
\text { people in the airplane across the oceans }\end{array}$ & 89 & 90 & 82 & 83 & 86 \\
\hline & $\begin{array}{l}\text { The virus gets in the body of the birds and } \\
\text { flies with birds across the ocean }\end{array}$ & 3 & 6 & 6 & 13 & 7 \\
\hline
\end{tabular}


Table 2 (continued)

\begin{tabular}{|c|c|c|c|c|c|c|}
\hline \multirow[t]{2}{*}{ Survey question } & \multirow[t]{2}{*}{ Response from $>10 \%$ of students } & \multicolumn{5}{|c|}{$\begin{array}{l}\text { Percent of students who chose the given answer } \\
\text { Fall } 2020\end{array}$} \\
\hline & & $\begin{array}{l}\text { Freshman } \\
\text { STEM }\end{array}$ & $\begin{array}{l}\text { Freshman } \\
\text { STEM }\end{array}$ & $\begin{array}{l}\text { Senior } \\
\text { STEM }\end{array}$ & $\begin{array}{l}\text { Introductory } \\
\text { Non-STEM }\end{array}$ & AVG \\
\hline \multirow[t]{3}{*}{$\begin{array}{l}\text { As it travels, does the virus stay the same, } \\
\text { or does it change? }\end{array}$} & $\begin{array}{l}\text { Virus has RNA which undergoes mutation } \\
\text { once every } 1.5 \text { to } 2 \text { months, changing its } \\
\text { gene }\end{array}$ & 57 & 58 & 58 & 42 & 54 \\
\hline & $\begin{array}{l}\text { The genetic make-up of the SARS-COV-2 } \\
\text { virus which causes COVID-19 always } \\
\text { stays constant }\end{array}$ & 29 & 26 & 33 & 38 & 31 \\
\hline & $\begin{array}{l}\text { Bacteria are known to change their genes, } \\
\text { but not viruses }\end{array}$ & 14 & 13 & 6 & 17 & 12 \\
\hline \multirow[t]{3}{*}{$\begin{array}{l}\text { Do mutations in SARS-COV-2 virus influ- } \\
\text { ence effect how we fight it? }\end{array}$} & $\begin{array}{l}\text { Yes, all treatments and preventive measures } \\
\text { may be effected depending on the type of } \\
\text { mutation }\end{array}$ & 74 & 74 & 64 & 54 & 67 \\
\hline & $\begin{array}{l}\text { If the genetic make-up of the virus changes, } \\
\text { drugs will not work, but vaccines will } \\
\text { work }\end{array}$ & 11 & 10 & 15 & 13 & 12 \\
\hline & $\begin{array}{l}\text { If virus changes its genes, our body can } \\
\text { quickly change its genes to match virus's } \\
\text { gene }\end{array}$ & 9 & 10 & 15 & 21 & 14 \\
\hline \multirow[t]{2}{*}{ How does a vaccine work? } & $\begin{array}{l}\text { vaccines work by training body to prepare } \\
\text { for potential viral attacks }\end{array}$ & 100 & 87 & 76 & 79 & 86 \\
\hline & $\begin{array}{l}\text { Vaccines are a kind of medicine. They } \\
\text { work by going into our cells and killing } \\
\text { the virus }\end{array}$ & 0 & 13 & 18 & 13 & 11 \\
\hline \multirow[t]{2}{*}{$\begin{array}{l}\text { How does our body defend itself against a } \\
\text { virus? }\end{array}$} & $\begin{array}{l}\text { Our body makes antibodies which engulf } \\
\text { various parts of the virus preventing } \\
\text { infection }\end{array}$ & 86 & 84 & 82 & 75 & 82 \\
\hline & $\begin{array}{l}\text { our red blood cells which are in charge of } \\
\text { attacking foreign bodies, attack and kill } \\
\text { the virus }\end{array}$ & 9 & 6 & 12 & 13 & 10 \\
\hline \multirow{2}{*}{$\begin{array}{l}\text { Name the field that studies the spread of } \\
\text { infectious disease across the world }\end{array}$} & Epidemiology & 74 & 71 & 73 & 50 & 67 \\
\hline & Pandemic & 23 & 19 & 27 & 46 & 29 \\
\hline \multirow[t]{2}{*}{$\begin{array}{l}\text { What is the difference between pandemic } \\
\text { and epidemic? }\end{array}$} & $\begin{array}{l}\text { in pandemic, a disease is spread over larger } \\
\text { area compared to epidemic }\end{array}$ & 91 & 90 & 73 & 92 & 87 \\
\hline & $\begin{array}{l}\text { In epidemic, a disease is spread over much } \\
\text { larger area compared to pandemic }\end{array}$ & 9 & 6 & 27 & 4 & 12 \\
\hline \multirow[t]{2}{*}{$\begin{array}{l}\text { What is the purpose of testing in COVID- } \\
19 ?\end{array}$} & $\begin{array}{l}\text { To find out if a person is carrying the virus } \\
\text { now or has had the virus in the past }\end{array}$ & 46 & 74 & 64 & 54 & 59 \\
\hline & To learn only if a person has the virus now. & 54 & 23 & 36 & 38 & 38 \\
\hline \multirow[t]{3}{*}{$\begin{array}{l}\text { How many types of test exist for COVID- } \\
19 \text { ? What do we learn from them? }\end{array}$} & $\begin{array}{l}\text { Genetic test shows if virus is present now; } \\
\text { antibody test shows if virus has been } \\
\text { present in the past }\end{array}$ & 37 & 74 & 36 & 42 & 47 \\
\hline & $\begin{array}{l}\text { Antibody test shows if virus is present } \\
\text { now; genetic test shows if virus has been } \\
\text { present in the past }\end{array}$ & 23 & 13 & 27 & 21 & 21 \\
\hline & $\begin{array}{l}\text { Both types of test show if virus is present } \\
\text { in the body of the subject whose sample } \\
\text { is being tested }\end{array}$ & 40 & 13 & 33 & 33 & 30 \\
\hline \multirow[t]{3}{*}{$\begin{array}{l}\text { Is there any drug present now that will help } \\
\text { cure COVID-19 patients? }\end{array}$} & $\begin{array}{l}\text { There are old drugs that were made to fight } \\
\text { other diseases that are being used to help } \\
\text { COVID patients }\end{array}$ & 60 & 71 & 30 & 23 & 46 \\
\hline & COVID-19 has no drug & 6 & 23 & 67 & 33 & 32 \\
\hline & $\begin{array}{l}\text { Only traditional medicines have been } \\
\text { proven to help COVID-19 patients }\end{array}$ & 3 & 3 & 0 & 25 & 8 \\
\hline
\end{tabular}


Table 2 (continued)

\begin{tabular}{|c|c|c|c|c|c|c|}
\hline \multirow[t]{2}{*}{ Survey question } & \multirow[t]{2}{*}{ Response from $>10 \%$ of students } & \multicolumn{5}{|c|}{$\begin{array}{l}\text { Percent of students who chose the given answer } \\
\text { Fall } 2020\end{array}$} \\
\hline & & $\begin{array}{l}\text { Freshman } \\
\text { STEM }\end{array}$ & $\begin{array}{l}\text { Freshman } \\
\text { STEM }\end{array}$ & $\begin{array}{l}\text { Senior } \\
\text { STEM }\end{array}$ & $\begin{array}{l}\text { Introductory } \\
\text { Non-STEM }\end{array}$ & AVG \\
\hline \multirow{4}{*}{$\begin{array}{l}\text { Can you name one drug that was recently } \\
\text { registered to work against COVID-19? }\end{array}$} & Remdesivir & 46 & 77 & 42 & 46 & 53 \\
\hline & Aspirin & 9 & 10 & 6 & 21 & 11 \\
\hline & Dexamethasone & 34 & 6 & 36 & 17 & 23 \\
\hline & Paclitaxel & 11 & 6 & 12 & 17 & 12 \\
\hline \multirow[t]{3}{*}{$\begin{array}{l}\text { Is there a vaccine against COVID-19? If so, } \\
\text { who is the manufacturer? }\end{array}$} & $\begin{array}{l}\text { No vaccine has been registered against } \\
\text { COVID-19 yet }\end{array}$ & 60 & 84 & 70 & 58 & 68 \\
\hline & Yes, the company name is Moderna & 11 & 3 & 6 & 13 & 8 \\
\hline & Yes, the company name is Pfizer & 26 & 10 & 18 & 25 & 20 \\
\hline \multirow[t]{2}{*}{$\begin{array}{l}\text { What major challenges related COVID-19 } \\
\text { are hospitals and their staff still facing? }\end{array}$} & $\begin{array}{l}\text { Not having enough PPE for medical staff } \\
\text { and not many treatment options available }\end{array}$ & 94 & 84 & 91 & 71 & 85 \\
\hline & $\begin{array}{l}\text { Inability of the medical staff to take the } \\
\text { available vaccines }\end{array}$ & 0 & 10 & 6 & 13 & 7 \\
\hline \multirow[t]{3}{*}{$\begin{array}{l}\text { Does advice of the scientists help or hurt } \\
\text { the efforts to end the pandemic? }\end{array}$} & $\begin{array}{l}\text { Only science and following the advice } \\
\text { of scientists will help us get rid of the } \\
\text { pandemic }\end{array}$ & 86 & 90 & 73 & 83 & 83 \\
\hline & $\begin{array}{l}\text { Scientists are only interested in protecting } \\
\text { themselves and their families that is why } \\
\text { they do the work }\end{array}$ & 6 & 3 & 9 & 8 & 7 \\
\hline & $\begin{array}{l}\text { Depending on where they are from, } \\
\text { scientists may do good, or bad against } \\
\text { pandemic }\end{array}$ & 6 & 3 & 12 & 4 & 6 \\
\hline \multirow[t]{2}{*}{$\begin{array}{l}\text { What does the SARS-COV-2 virus looks } \\
\text { like? }\end{array}$} & $\begin{array}{l}\text { SARS-COV-2 looks like a tennis ball with } \\
\text { about } 200 \text { spikes on its surface }\end{array}$ & 83 & 84 & 79 & 50 & 74 \\
\hline & SARS-COV-2 looks like a worm & 6 & 3 & 3 & 13 & 6 \\
\hline \multirow[t]{4}{*}{$\begin{array}{l}\text { How does viral genome of SARS-COV-2 } \\
\text { compare with that of human genome? }\end{array}$} & $\begin{array}{l}\text { SARS-COV-2 RNA has } 29,000 \text { bases, } \\
\text { human DNA has millions }\end{array}$ & 40 & 71 & 52 & 58 & 55 \\
\hline & $\begin{array}{l}\text { Human DNA and SARS-COV-2 RNA are } \\
\text { the same size }\end{array}$ & 17 & 10 & 6 & 17 & 12 \\
\hline & $\begin{array}{l}\text { Human DNA is slightly longer than SARS- } \\
\text { COV-2 RNA }\end{array}$ & 29 & 19 & 24 & 21 & 23 \\
\hline & $\begin{array}{l}\text { SARS-COV-2 RNA is longer than human } \\
\text { DNA }\end{array}$ & 14 & 0 & 18 & 4 & 9 \\
\hline \multirow[t]{6}{*}{ HOW SARS-COV-2 infects people? } & $\begin{array}{l}\text { virus uses its spike protein (S-protein) } \\
\text { to interact with ACE- } 2 \text { receptor on the } \\
\text { surface of lung cells to infect people }\end{array}$ & 80 & 81 & 82 & 54 & 74 \\
\hline & $\begin{array}{l}\text { The virus can infect all cells in our body } \\
\text { regardless of the type }\end{array}$ & 11 & 16 & 12 & 33 & 18 \\
\hline & $\begin{array}{l}\text { The main site of attack of virus is lung and } \\
\text { where virus enters the cells and it uses its } \\
\text { machinery to multiply }\end{array}$ & 71 & 81 & 76 & 63 & 73 \\
\hline & $\begin{array}{l}\text { The virus is able to synthesize everything } \\
\text { that it needs for its multiplication inde- } \\
\text { pendent of our cells }\end{array}$ & 20 & 6 & 6 & 8 & 10 \\
\hline & $\begin{array}{l}\text { The virus uses some proteins from our cells } \\
\text { but most from his own body that it needs } \\
\text { for multiplication }\end{array}$ & 6 & 6 & 9 & 17 & 9 \\
\hline & $\begin{array}{l}\text { The virus can adapt to changes within our } \\
\text { body and change its way of surviving }\end{array}$ & 3 & 6 & 9 & 13 & 8 \\
\hline $\begin{array}{l}\text { What main characteristic of the COVID-19 } \\
\text { makes it very dangerous? }\end{array}$ & $\begin{array}{l}\text { The fact that it is very contagious and } \\
\text { many people who are infected, show no } \\
\text { symptoms }\end{array}$ & 89 & 94 & 85 & 75 & 85 \\
\hline
\end{tabular}


Table 2 (continued)

\begin{tabular}{|c|c|c|c|c|c|c|}
\hline \multirow[t]{2}{*}{ Survey question } & \multirow[t]{2}{*}{ Response from $>10 \%$ of students } & \multicolumn{5}{|c|}{$\begin{array}{l}\text { Percent of students who chose the given answer } \\
\text { Fall } 2020\end{array}$} \\
\hline & & $\begin{array}{l}\text { Freshman } \\
\text { STEM }\end{array}$ & $\begin{array}{l}\text { Freshman } \\
\text { STEM }\end{array}$ & $\begin{array}{l}\text { Senior } \\
\text { STEM }\end{array}$ & $\begin{array}{l}\text { Introductory } \\
\text { Non-STEM }\end{array}$ & AVG \\
\hline \multirow[t]{2}{*}{$\begin{array}{l}\text { What has been the contribution of scientists } \\
\text { in the course of COVID-19 pandemic? }\end{array}$} & $\begin{array}{l}\text { Scientists have worked hard to find solu- } \\
\text { tions to fight the SARS-COV-2 virus }\end{array}$ & 74 & 94 & 85 & 71 & 81 \\
\hline & $\begin{array}{l}\text { Scientists have been the main source of } \\
\text { problem since they advise that govern- } \\
\text { ments close everything down }\end{array}$ & 20 & 3 & 6 & 21 & 13 \\
\hline \multirow{2}{*}{$\begin{array}{l}\text { During what stage of the SARS-COV-2 } \\
\text { infection, people are most contagious? }\end{array}$} & First 3 days after infection & 74 & 90 & 73 & 71 & 77 \\
\hline & Day 7 of infection & 14 & 6 & 21 & 25 & 17 \\
\hline \multirow[t]{2}{*}{$\begin{array}{l}\text { Why we have fever when infected with } \\
\text { SARS-COV-2 virus? }\end{array}$} & $\begin{array}{l}\text { fever is a sign that our body is fighting the } \\
\text { virus }\end{array}$ & 80 & 90 & 82 & 71 & 81 \\
\hline & $\begin{array}{l}\text { We should isolate ourselves as soon as } \\
\text { fever appears }\end{array}$ & 9 & 6 & 12 & 17 & 11 \\
\hline \multirow[t]{3}{*}{ What type of virus is SARS-COV-2? } & SARS-COV-2 is a RNA virus & 63 & 84 & 88 & 54 & 72 \\
\hline & SARS-COV-2 is type of bacteria & 17 & 16 & 3 & 21 & 14 \\
\hline & SARS-COV-2 is both DNA and RNA virus & 3 & 0 & 9 & 13 & 6 \\
\hline
\end{tabular}

are infected has been coming down, starting from $>60$ at the beginning of the year, changing to 20-29 during the latter part of the year. As a result, during the latter part of 2020 and early 2021, incidence of infection among 20-29-yearolds accounted for $>20 \%$ of all confirmed cases (Fig. 7) [46]. To avoid infecting older members of their families, in the USA, some younger adults stayed in shelter [55], but in countries like China, everyone including young showed high level of awareness and knowledge about COVID-19 and helped prevent the transmission to older adults [56].
Many young Black and Brown college students in the USA work as first responders, nurses, store clerks, and at other similar positions. Working in such functions enhances young people's chance of exposure to the SARS-COV-2 virus and its transmission to elderly in their communities. Transmission to communities can potentially occur when students return home to their families for spring or fall breaks. Thus far, role of young Black and Brown college students in transmission of COVID-19 to Black and Brown communities has not been investigated. Also, no study has looked at the knowledge level of students about
Fig. 5 Percent of students who selected a given response is plotted against the responses that those students chose, among the multiple choices provided to them. As shown, percent of students who correctly chose the responses related to "how to be safe from catching or transmitting the COVID-19", were high

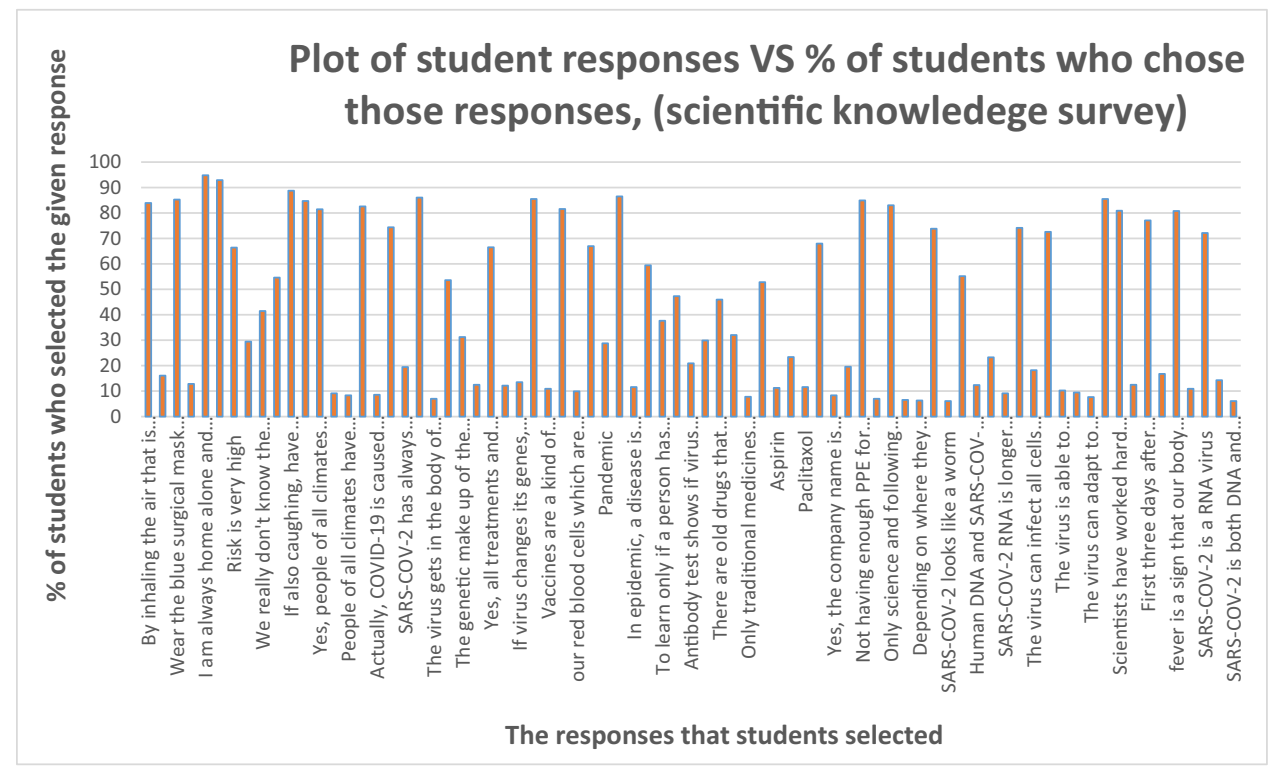




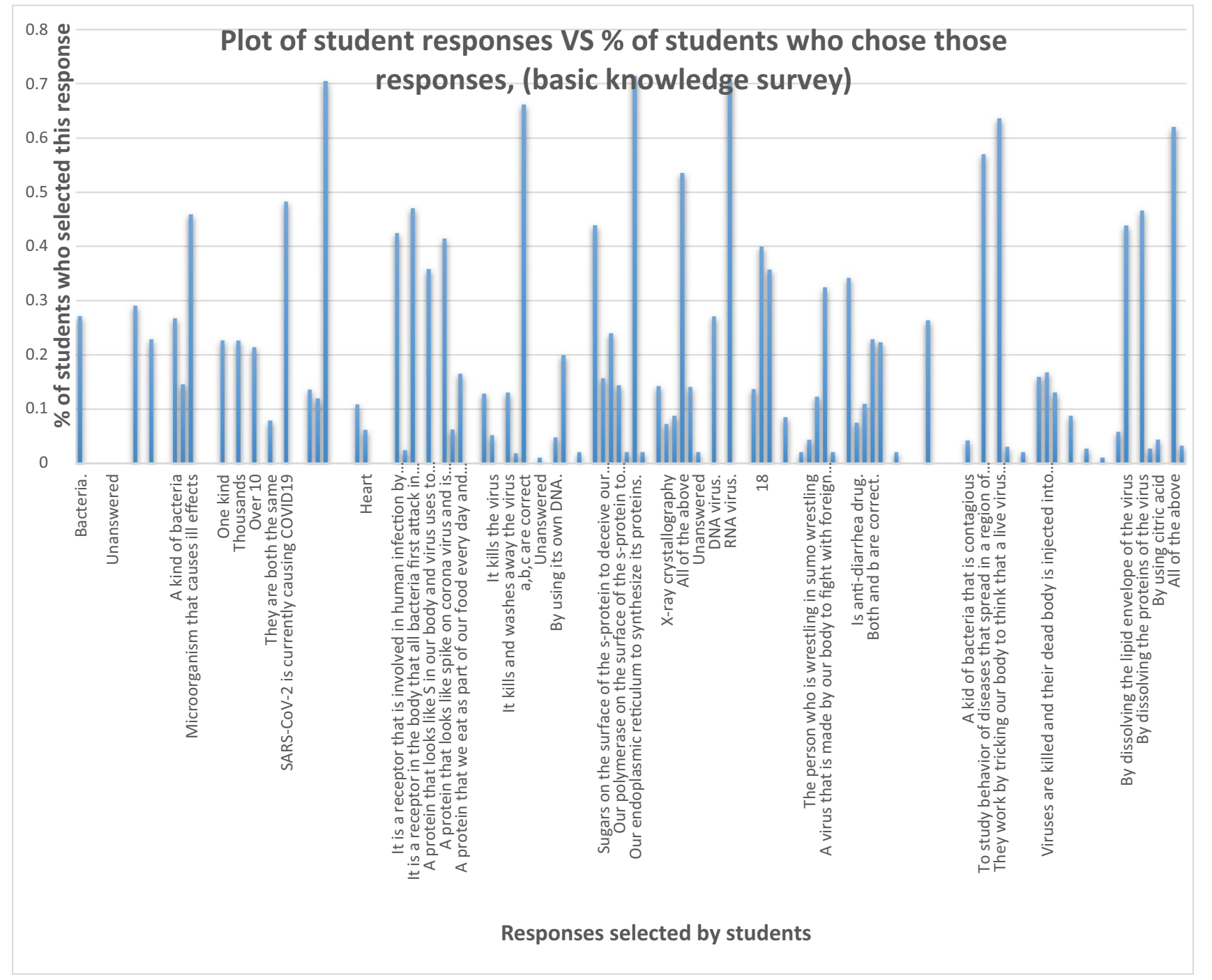

Fig. 6 Percent of students who selected the correct response for the scientific questions about SARS-COV-2 and COVID-19 disease. Percent of students who selected those responses against the response is plotted

the SARS-COV-2 and COVID-19 and the role that student knowledge about the virus safety plays in the transmission of the disease to the minority communities. In this study, we gauged the knowledge base of undergraduate students about COVID-19 at North Carolina A\&T State University which is an HBCU. We hypothesized that if students are knowledgeable about the safety precautions, they will take steps to prevent infection and transmission to their communities. On the other hand, if they are not knowledgeable about the dangers of the disease and how it is transmitted, they may unknowingly transmit the disease to elderly in their family and communities and cause infections and contribute to higher death rate.

In addition to assessing the overall student knowledge about COVID-19, we also were interested in learning whether STEM majors would exhibit a better understanding of COVID-19. Many non-STEM students are required to complete an introductory chemistry courses at NCAT. It is common for these students to have little to no prior experience with chemistry, biology, or other related fields. First year STEM majors have demonstrated an interest in these fields but may not have much experience outside of high school classes. Many STEM majors are required to take chemistry and biology courses that may have covered topics related to disease transmission and infection. Since senior STEM students have already taken college-level science courses, we also hypothesized that senior STEM students would demonstrate greater understanding of COVID-19 and SARS-COV-2.

As shown in Tables 1 and 2 and Figs. 5 and 6, an average of ninety $(90 \%)$ percent of the students in the study across all classes accurately defined the term "pandemic." 


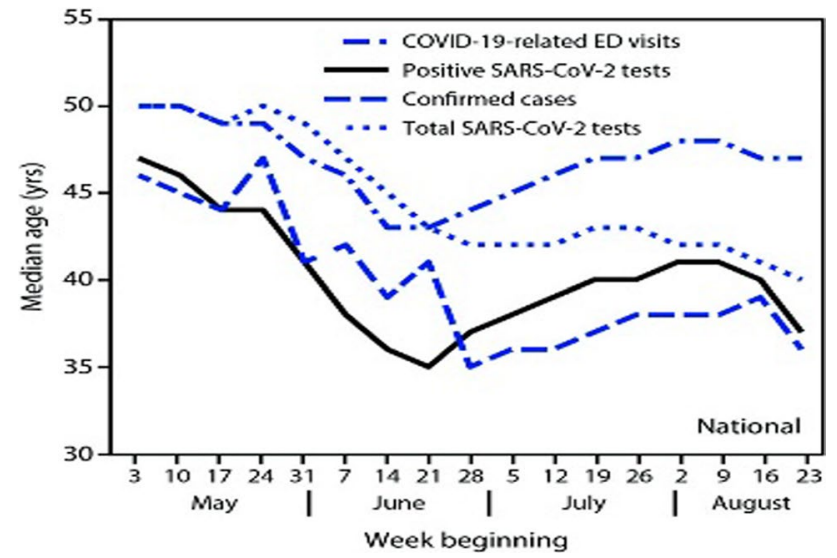

Fig. 7 The increase in percent positivity in SARS-COV-2 tests among 20-39 years old adults which occurred days before the increase in positivity among older adults, indicates that younger adults contributed to transmission of COVID-19 to older adults [46]

The percent correct ranged from 86 to $100 \%$ in different classes. In the summer of $2020,46 \%$ of freshmen students knew a pathogen is a foreign object that enters the body and causes pathological effects, seventy-two $(71.7 \%)$ percent of all students enrolled in the introductory chemistry courses knew that COVID-19 is caused by a virus and not a bacteria, fungi, or archaea, the percent of students who chose the correct answers ranged from 56 to $93 \%$ between classes; $48 \%$ correctly identified SARS-COV-2 as the virus that is causing COVID-19. In the fall semester of $2020,83 \%$ of all students and $67 \%$ of freshmen knew that COVID-19 is caused by a virus; nine percent overall, $17 \%$ of freshman thought COVID-19 is caused by a bacteria. While in the summer of 2020, seventy percent of all students (70\%) knew that people are infected with COVID-19 virus by direct contact, in the fall, $84 \%$ knew that virus is transmitted through the air. As for the origin of the virus that causes COVID, $74 \%$ overall and $67 \%$ of freshmen knew that the virus had zoonotic origin; $19 \%$ of all students and $21 \%$ of freshman thought that the virus has always been among human population. Forty-four percent of the students thought that the word corona was derived from the "corona plant." Twentyone percent $(21 \%)$ of the students agreed that there are over 10 types of corona viruses. In testing student's knowledge about the virus itself, $74 \%$ overall (50\% of freshmen) knew that SARS-COV-2 virus looks like a tennis ball with spikes on its surface, and $72 \%$ overall ( $54 \%$ freshmen $(\mathrm{F})$ ) knew that SARS-COV-2 is a RNA virus, while 55\% agreed that its genome is much smaller than the human genome. Still, in the fall, 14\% (21\% F) thought a bacteria causes COVID-19. Over half of the students (74\% all, 54\% freshmen) knew that the virus uses its spike protein to infect host cells, $73 \%$ of all, $63 \%$ of freshmen, agreed that the lung is the main site for the attack of the virus. Majority of students $(77,71 \%$ F) knew that an infected person is most contagious during the first 3 days after infection, and the main danger coming from the virus is due to its high contagiousness and $(85 \%$ all, $75 \% \mathrm{~F})$ due to the fact that many infected people show no symptoms. Fewer than $30 \%$ (17\% overall, 25\% freshmen) agreed that an infected person is most infectious on day 7 of infection. On fever, most ( $81 \%$ overall, $71 \%$ freshmen) agreed that fever is a sign that our body is fighting with the infection.

On the effect of climate on getting infected with SARS-COV-2 virus, $82 \%$ overall and $71 \%$ of freshman thought that people in any climate can catch COVID-19. When asked how the virus travels across the oceans, they chose the option that says, virus travels with infected people who travel (86\% overall, $83 \%$ freshmen) across the ocean. Over half of the respondents chose the definition of epidemiology correctly (answer choice: Epidemiology is the name of the field that studies spread of infectious diseases, $67 \%$ overall, $50 \%$ freshmen), but about $29 \%$ of all students $(46 \%$ of freshmen) confused epidemiology with pandemic. When asked to compare pandemic with epidemic, most chose the correct response which said, "Pandemic covers larger area than epidemic" (87\% overall, $92 \%$ freshmen).

In the fall of 2020 , over $80 \%$ of all students and over $75 \%$ of the freshmen knew that COVID-19 is transmitted through inhalation of the air exhaled by an infected person. Sixteen percent of all and $25 \%$ of freshmen thought that transmission can occur even with mask, gloves, and shield. Eighty-five percent of all and $75 \%$ of the freshmen thought that they are $100 \%$ protected if they wear surgical masks outside and wash their hands once inside. Still $13 \%$ of all students and $21 \%$ of freshman think that only staying $6 \mathrm{ft}$ away from people that "they think" are infected will keep them safe. Of course, knowing that a great number of infected people look and feel normal, it is difficult to decide who is and who is not infected. Ninety-five percent of all and $92 \%$ of freshmen think that if they are isolated at home at all times, they will be safe from catching the virus. About half of respondents $(59 \%, 54 \% \mathrm{~F})$ knew that the purpose of testing is to learn if a person is currently infected or has been infected in the past, and 38\% thought the purpose of testing is only to see if someone is infected now. Only $47 \%$ knew that genetic testing like PCR shows current infection, but antibody testing shows past infection, $21 \%$ thought the opposite was true, and $30 \%$ thought both tests show current infection.

Ninety-three percent of all students and $96 \%$ of freshmen knew that people with breathing and heart problems, diabetes, and obesity are more susceptible and in danger of dying from COVID-19. But $66 \%$ thought that people with COPD are at high risk. Fifty-five percent thought that having 
common flu puts them at a higher risk level if combined with COVID-19. If having a heart attack and knowing that hospitals are full of COVID-19 patients, will they choose to go to hospital immediately or not? $85 \%$ of all students and $75 \%$ of freshman answered yes. This is reassuring since a person suffering from heart attack may end up dying if not helped by professionals, but the majority of people who are infected with SARS-COV-2 are not at risk of dying.

Regarding mutation, more students (54\% all, $42 \%$ freshman) agree that the virus mutates vs fewer who don't (31\% all, $38 \%$ freshman). Students also agree that mutations may influence the behavior of the virus so that treatments and vaccines may have to be modified (67\% all, 54\% freshmen). But, about a third (31\% all, 38\% freshmen) of the students think that the genetic makeup of the virus normally does not change as a result of mutation, and if it did change, our genes also will change (14\% all, $21 \%$ freshmen) accordingly.

A large majority of students ( $86 \%$ all, $79 \%$ freshmen) agree that vaccines work by preparing our body to fight potential viruses. About one-tenth (11\% all, 13\% freshmen) of the students think vaccines are like medicines that kill the virus in our cells. When it comes to vaccines, in the fall, $68 \%$ of all students ( $58 \%$ of freshmen) believed there was no vaccine available against COVID-19; still, 20\% knew about Pfizer's vaccine and $8 \%$ about Moderna's vaccine. About $80 \%$ ( $82 \%$ all, $75 \%$ freshmen) of the respondents agree that our bodies make antibodies to defend itself against the virus. But $10 \%$ of the students think that the red blood cells are in charge of defending the body (10\% all, $13 \%$ freshmen).

For treatment, $46 \%$ knew that old drugs are repurposed to treat COVID-19 patients, $32 \%$ thought no drug is available for treatment of COVID-19, and $8 \%$ of all students (25\% freshmen) thought only traditional medicines have proven useful in helping COVID-19 patients. About half (53\% of all students (46\% freshmen) knew remdesivir was recently approved, but $23 \%$ (17\% of freshmen) thought dexamethasone was recently registered to be used against COVID.

Most respondents (85\% all, 71\% freshmen) knew that hospitals had major challenges in acquiring enough PPE for their everyday use. Likewise, greater than $80 \%$ of students ( $83 \%$ all, $83 \%$ freshmen) believed that listening to the advice of scientists will help humanity get rid of the pandemic. Most ( $81 \%$ overall, $71 \%$ freshmen) agreed that scientists have worked hard to find solutions for this problem, but $13 \%$ (21\% of freshmen) thought that scientists have been the source of the problems during COVID-19 pandemic. Adding special topics to the curriculum that highlight chemistry and its role in detection, prevention, and treatment of the diseases may help build student trust in the capabilities of the scientific community in solving such problems. In addition, it will encourage students to pursue research careers that will enable them solve such complex problems as pandemic.
We were also interested in learning whether STEM students would have an increased understanding of COVID-19 in comparison to their non-STEM peers. Students in three of the courses surveyed were STEM majors-ranging from chemistry to biology to animal science. The other three courses are for non-science majors. The average percentage of correct answers was calculated, and a $t$ test used to determine if the differences between STEM student knowledge and non-STEM student knowledge were due to more than random chance. Surprisingly, the results of the $t$ test indicate that there is no statistically significant difference between the two student populations ( $p=0.97$, data not shown). This suggests other factors, such as access to news sources with up-to-date information on the pandemic and student motivation to keep themselves and their families safe and healthy, may have played a role in diminishing the COVID-19 knowledge gap between STEM and nonSTEM students. Comparing survey results from first year STEM students with senior STEM students, we found no significant difference. One pitfall of this analysis is that only one class of senior STEM students was surveyed. Despite the surprising results, it demonstrates that when properly motivated and information is easily accessible, students can learn, retain, and apply scientific knowledge to keep themselves and their communities safe.

\section{Conclusion}

Analysis of our COVID-19 student survey results show that for the most part, our students know the general safety guidelines about COVID-19 to avoid infection and to avoid spreading of the disease to others in their communities. We did not investigate where the students get their information, but, most have some level of knowledge about the structure and function of SARS-COV-2, the virus that causes COVID19 , and they would follow scientists' advice about testing and vaccines. Students lacking in-depth knowledge about the virus and the disease and the available protection devices include first year non-science majors who were enrolled in introductory chemistry courses. For these students, basic scientific and general health and safety knowledge and guidelines can be provided through basic science courses such as chemistry by incorporating relevant concepts in curriculum through replacement or modification of current topics. Such modifications which must be accompanied with critical thinking and academic support will allow enhancement of the knowledge base of students and will also serve as stepping stone to enhance the knowledge base of Black and Brown communities as a whole. Imbedding such information in STEM classes' curriculum will serve to increase the confidence level of the students which will allow them to serve as advisors for those in the family or community 
who are hesitant to see a doctor or receive a vaccine. Some students may become interested in performing research in health related fields and remain in higher education.

Acknowledgements The authors thank Mr. John Teleha for his assistance with the references.

Author Contribution Both authors contributed to the study conception and design. Material preparation, data collection, and analysis were performed by Jahangir Emrani. The first draft of the manuscript was written by Jahangir Emrani. Both authors edited and commented on previous versions of the manuscript and modified the text and figures. Both authors read and approved the final manuscript.

Conceptualization, Jahangir Emrani; methodology, Jahangir Emrani; formal analysis and investigation, Jahangir Emrani and Elia Hefner; writing, original draft preparation, Jahangir Emrani; writing, review and editing, Jahangir Emrani and Elia Hefner.

\section{Declarations}

Ethics Approval Ethical approval was waived by the local Ethics Committee of North Carolina A\&T State University since no identifier information about the subjects were included in the data and the manuscript.

Conflict of Interest The authors declare no competing interests.

\section{References}

1. Jiang S, Xia S, Ying T, et al. A novel coronavirus (2019$\mathrm{nCoV}$ ) causing pneumonia-associated respiratory syndrome. Cell Mol Immunol. 2020;17(5):554. https://doi.org/10.1038/ s41423-020-0372-4.

2. Alcendor DJ. Racial disparities-associated COVID-19 mortality among minority populations in the US. J Clin Med. 2020;9(8):2442. https://doi.org/10.3390/jcm9082442.

3. Holmes L, Enwere M, Williams J, et al. Black-white risk differentials in COVID-19 (SARS-COV2) transmission, mortality and case fatality in the United States: translational epidemiologic perspective and challenges. Int J Environ Res Public Health. 2020;17(12):4322. https://doi.org/10.3390/ijerph17124322.

4. Garg S. Hospitalization rates and characteristics of patients hospitalized with laboratory-confirmed coronavirus disease 2019COVID-NET, 14 States, March 1-30, 2020. MMWR Morb Mortal Wkly Rep. 2020;69(15):458-64. https://doi.org/10.15585/mmwr. mm6915e3.

5. Kullar R, Marcelin JR, Swartz TH, et al. Racial disparity of coronavirus disease 2019 in African American communities. J Infect Dis. 2020;222(6):890-3. https://doi.org/10.1093/infdis/jiaa372.

6. Manchanda ECC, Sanky C, Appel JM. Crisis standards of care in the USA: a systematic review and implications for equity amidst COVID-19. J Racial Ethn Health Disparities. 2021;8:824-36. https://doi.org/10.1007/s40615-020-00840-5.

7. Cowger TL, Davis BA, Etkins OS, et al. Comparison of weighted and unweighted population data to assess inequities in coronavirus disease 2019 deaths by race/ethnicity reported by the US Centers for Disease Control and Prevention. JAMA Netw Open. 2020;3(7):e2016933. https://doi.org/10.1001/jamanetworkopen. 2020.16933.

8. Attia ZI, Kapa S, Lopez-Jimenez F, et al. Screening for cardiac contractile dysfunction using an artificial intelligence-enabled electrocardiogram. Nat Med. 2019;25(1):70-4. https://doi.org/ 10.1038/s41591-018-0240-2.

9. Ziegler CGK, Allon SJ, Nyquist SK, et al. SARS-CoV-2 receptor ACE2 is an interferon-stimulated gene in human airway epithelial cells and is detected in specific cell subsets across tissues. Cell. 2020;181(5):1016-1035.e19. https://doi.org/10.1016/j.cell.2020. 04.035 .

10. Laurini E, Marson D, Aulic S, et al. Computational alanine scanning and structural analysis of the SARS-CoV-2 spike protein/angiotensin-converting enzyme 2 complex. ACS Nano. 2020;14(9):11821-30. https://doi.org/10.1021/acsnano.0c04674.

11. Howes L. Structural biologists, assemble! C\&EN Global Enterp. 2021;99(12):18-9. https://doi.org/10.1021/cen-09912-feature1.

12. Fehr AR, Perlman S. Coronaviruses: an overview of their replication and pathogenesis. In: Maier HJ, Bickerton E, Britton P (eds) Coronaviruses: methods and protocols. Methods in molecular biology, vol 1282. New York: Humana Press; 2015. pp. 1-23. https://doi.org/10.1007/978-1-4939-2438-7_1.

13. Muus C, Luecken MD, Eraslan G, et al. Integrated analyses of single-cell atlases reveal age, gender, and smoking status associations with cell type-specific expression of mediators of SARS-CoV-2 viral entry and highlights inflammatory programs in putative target cells. bioRxiv. 2020; 2020.04.19.049254. https://doi.org/10. 1101/2020.04.19.049254.

14. Chowdhury R, Boorla VS, Maranas CD. Computational biophysical characterization of the SARS-CoV-2 spike protein binding with the ACE2 receptor and implications for infectivity. Comput Struct Biotechnol J. 2020;18:2573-82. https://doi.org/10.1016/j. csbj.2020.09.019.

15. Zhou D, Dejnirattisai W, Supasa P, et al. Evidence of escape of SARS-CoV-2 variant B. 1. 351 from natural and vaccine-induced sera. Cell. 2021;184(9):2348-61. https://doi.org/10.1016/j.cell.2021. 02.037 .

16. Ortuso F, Mercatelli D, Guzzi PH, et al. Structural genetics of circulating variants affecting the SARS-CoV-2 spike/human ACE2 complex. J Biomol Struct Dyn In Press. 2021. https://doi.org/10. 1080/07391102.2021.1886175.

17. O’Dowd K, Nair KM, Forouzandeh P, et al. Face masks and respirators in the fight against the COVID-19 pandemic: a review of current materials, advances and future perspectives. Materials. 2020;13(15):3363. https://doi.org/10.3390/ma13153363.

18. Gordon DE, Jang GM, Bouhaddou M, et al. A SARS-CoV-2 protein interaction map reveals targets for drug repurposing. Nature. 2020;583(7816):459-68. https://doi.org/10.1038/ s41586-020-2286-9.

19. Dai W, Zhang B, Jiang X, et al. Structure-based design of antiviral drug candidates targeting the SARS-CoV-2 main protease. Science. 2020;368(6497):1331-5. https://doi.org/10.1126/scien ce.abb4489.

20. Muhammed Y, Usman J, Aliyu AM, et al. The response of Nigerian government to COVID-19: patient management and diagnosis-a mini-review. Int J Sci Global Sustain. 2020;6(4):9-16.

21. Lam Cabanillas E, León Risco A, León Risco K, et al. Molecular basis of COVID-19 pathogenesis and in silico studies of potential pharmacological treatment. Revista de la Facultad de Medicina Humana. 2021; 21(2):22.

22. Romano M, Ruggiero A, Squeglia F, et al. A structural view of SARS-CoV-2 RNA replication machinery: RNA synthesis, proofreading and final capping. Cells. 2020;9(5):1267. https://doi.org/ 10.3390/cells9051267.

23. Burda P, Aebi M. The dolichol pathway of N-linked glycosylation. Biochim Biophys Acta. 1999;1426(2):239-57. https://doi.org/10. 1016/S0304-4165(98)00127-5.

24. Agostini ML, Andres EL, Sims AC, et al. Coronavirus susceptibility to the antiviral remdesivir (GS-5734) is mediated by the 
viral polymerase and the proofreading exoribonuclease. mBio. 2018;9(2):221. https://doi.org/10.1128/mBio.00221-18.

25. Grein J, Ohmagari N, Shin D, et al. Compassionate use of remdesivir for patients with severe COVID-19. N Engl J Med. 2020;382(24):2327-36. https://doi.org/10.1056/NEJMoa2007016.

26. Jarvis LM. Scaling up remdesivir amid the coronavirus crisis. C\&EN Global Enterp. 2020;98(17):23-4. https://doi.org/10.1021/ cen-09817-feature2.

27. Eastman RT, Roth JS, Brimacombe KR, et al. Remdesivir: a review of its discovery and development leading to emergency use authorization for treatment of COVID-19. ACS Cent Sci. 2020;6(5):672-83. https://doi.org/10.1021/acscentsci.0c00489.

28. Cross R, Howes L, Satyanarayana M. 8 tools that helped us tackle the coronavirus. C\&EN Global Enterp. 2021;99(3):38-43. https:// doi.org/10.1021/cen-09903-feature3.

29. Chen P, Nirula A, Heller B, et al. SARS-CoV-2 neutralizing antibody LY-CoV555 in outpatients with Covid-19. N Engl J Med. 2021;384(3):229-37. https://doi.org/10.1056/NEJMoa2029849.

30. Wajnberg A, Amanat F, Firpo A, et al. Robust neutralizing antibodies to SARS-CoV-2 infection persist for months. Science. 2020;370(6521):1227-30. https://doi.org/10.1126/science.abd77 28.

31. Dong Y, Dai T, Wei Y, et al. A systematic review of SARS-CoV-2 vaccine candidates. Signal Transduct Target Ther. 2020;5(1):1-14. https://doi.org/10.1038/s41392-020-00352-y.

32. Wang Z, Schmidt F, Weisblum Y, et al. mRNA vaccine-elicited antibodies to SARS-CoV-2 and circulating variants. Nature. 2021;592:616-22. https://doi.org/10.1038/s41586-021-03324-6.

33. Livingston EH, Malani PN, Creech CB. The Johnson \& Johnson vaccine for COVID-19. JAMA. 2021;325(15):1575. https://doi. org/10.1001/jama.2021.2927.

34. Emrani J, Ahmed M, Newman RH, et al. Introducing Chemistry Students to Emerging Technologies in Gene Editing, Their Applications, and Ethical Considerations. J Chem Educ. 2020;97(7):193143. https://doi.org/10.1021/acs.jchemed.9b01154.

35. Lu R, Wu X, Wan Z, et al. A novel reverse transcription loopmediated isothermal amplification method for rapid detection of SARS-CoV-2. Int J Mol Sci. 2020;21(8):2826. https://doi.org/10. 3390/ijms21082826.

36. Li Y, Yao L, Li J, et al. Stability issues of RT-PCR testing of SARS-CoV-2 for hospitalized patients clinically diagnosed with COVID-19. J Med Virol. 2020;92(7):903-8. https://doi.org/10. 1002/jmv.25786.

37. Chaouch M. Loop-mediated isothermal amplification (LAMP): an effective molecular point-of-care technique for the rapid diagnosis of coronavirus SARS-CoV-2. Rev Med Virol. 2021;31(6):e2215. https://doi.org/10.1002/rmv.2215.

38. Yin W, Mao C, Luan X, et al. Structural basis for inhibition of the RNA-dependent RNA polymerase from SARS-CoV-2 by remdesivir. Science. 2020;368(6498):1499-504. https://doi.org/10.1126/ science.abc 1560.

39. Kolilekas L, Loverdos K, Giannakaki S, et al. Can steroids reverse the severe COVID-19 induced "cytokine storm"? J Med Virol. 2020;92(11):2866-9. https://doi.org/10.1002/jmv.26165.

40. Günther S, Reinke PYA, Fernández-García Y, et al. X-ray screening identifies active site and allosteric inhibitors of SARS-CoV-2 main protease. Science. 2021;372(6542):642-6. https://doi.org/ 10.1126/science.abf7945.

41. AminJafari A, Ghasemi S. The possible of immunotherapy for COVID-19: A systematic review. Int Immunopharmacol. 2020;83:106455. https://doi.org/10.1016/j.intimp.2020.106455.

42. McCoy M. Lilly to test baricitinib against COVID-19. C\&EN Global Enterp. 2020;98(15):13. https://doi.org/10.1021/cen09815-buscon17.
43. Halford B. Ruxolitinib to be tested in fight against COVID-19. C\&EN Global Enterp. 2020;98(14):11. https://doi.org/10.1021/ cen-09814-buscon3.

44. Zhang $\mathrm{C}, \mathrm{Wu} \mathrm{Z}, \mathrm{Li}$ J, et al. Cytokine release syndrome in severe COVID-19: interleukin-6 receptor antagonist tocilizumab may be the key to reduce mortality. Int J Antimicrob Agents. 2020;55(5):105954. https://doi.org/10.1016/j.ijantimicag.2020. 105954.

45. Stockard J, Rohlfing CM, Richmond GL. Equity for women and underrepresented minorities in STEM: graduate experiences and career plans in chemistry. Proc Natl Acad Sci. 2021;118(4):e2020508118. https://doi.org/10.1073/pnas.20205 08118 .

46. Boehmer TK, DeVies J, Caruso E, et al. Changing age distribution of the COVID-19 pandemic-United States, May-August 2020. Morb Mortal Weekly Rep. 2020;69(39):1404. https://doi.org/10. 15585/mmwr.mm6939e1.

47. Liu T, Gong D, Xiao J, et al. Cluster infections play important roles in the rapid evolution of COVID-19 transmission: a systematic review. Int J Infect Dis. 2020;99:374-80. https://doi.org/10. 1016/j.ijid.2020.07.073.

48. Cheng KJG, Sun Y, Monnat SM. COVID-19 Death rates are higher in rural counties with larger shares of blacks and Hispanics. J Rural Health. 2020;36(4):602-8. https://doi.org/10.1111/jrh. 12511.

49. Garcia MA, Homan PA, García C, et al. The color of COVID-19: structural racism and the pandemic's disproportionate impact on older racial and ethnic minorities. J Gerontol B. 2021;76(3):e7580. https://doi.org/10.1093/geronb/gbaa114.

50. Bhattacharyya U, Thelma BK. Age-related gene expression alterations by SARS-CoV-2 infection contribute to poor prognosis in elderly. J Genet. 2020;99(1):1-9. https://doi.org/10.1007/ s12041-020-01233-7.

51. Lai C, Shih T, Ko W, et al. Severe acute respiratory syndrome coronavirus 2 (SARS-CoV-2) and corona virus disease-2019 (COVID-19): the epidemic and the challenges. Int J Antimicrob Agents. 2020;55(3):105924. https://doi.org/10.1016/j.ijantimicag. 2020.105924.

52. Amanat F, Krammer F. SARS-CoV-2 vaccines: status report. Immunity. 2020;52(4):583-9. https://doi.org/10.1016/j.immuni. 2020.03.007.

53. Acemoglu D, Chernozhukov V, Werning I, et al. Optimal targeted lockdowns in a multi-group SIR model. National Bureau of Economic Research Working Paper Series. 2020; 27102. https://doi. org/10.3386/w27102.

54. To KK, Hung IF, Ip JD, et al. COVID-19 re-infection by a phylogenetically distinct SARS-coronavirus- 2 strain confirmed by whole genome sequencing. Clin Infect Dis. 2021;73(9):e2946-51. https://doi.org/10.1093/cid/ciaa1275.

55. Cohen AK, Hoyt LT, Dull B. A Descriptive Study of COVID-19Related Experiences and Perspectives of a National Sample of College Students in Spring 2020. J Adolesc Health. 2020;67(3):36975. https://doi.org/10.1016/j.jadohealth.2020.06.009.

56. Ding Y, Du X, Li Q, et al. Risk perception of coronavirus disease 2019 (COVID-19) and its related factors among college students in China during quarantine. PLoS ONE. 2020;15(8):e0237626. https://doi.org/10.1371/journal.pone.0237626.

Publisher's Note Springer Nature remains neutral with regard to jurisdictional claims in published maps and institutional affiliations. 


\section{Authors and Affiliations}

Jahangir Emrani $^{1}$ - Elia Nichelle Hefner ${ }^{1}$

Elia Nichelle Hefner enhefner@ncat.edu
Department of Chemistry, North Carolina A\&T State University, Greensboro, NC 27410, USA 